\title{
PENGARUH MOTIVASI BELAJAR, GAYA BELAJAR, DAN LINGKUNGAN BELAJAR PADA HASIL BELAJAR EKONOMI DI SMA NEGERI 1 WRINGINANOM GRESIK
}

\author{
Muhammad Miftah Farid, Pasca Sarjana Unesa \\ miftahgresik@yahoo.co.id
}

\begin{abstract}
ABSTRAK
Penelitian ini bertujuan untuk menganalisis pengaruh motivasi belajar, gaya belajar dan lingkungan belajar pada hasil belajar ekonomi secara parsial maupun simultan. Populasi penelitian adalah seluruh siswa IPS sebanyak 314 orang dan jumlah sampel sebanyak 153 orang yang meliputi kelas X, XI, dan XII IPS di SMA Negeri 1 Wringinanom Gresik. Adapun teknik pengumpulan data yaitu angket dan dokumentasi. Metode analisis menggunakan teknik regresi linier berganda. Hasil penelitian menunjukkan bahwa motivasi belajar, gaya belajar dan lingkungan belajar secara parsial berpengaruh signifikan positif terhadap hasil belajar. Motivasi belajar, gaya belajar dan lingkungan belajar secara simultan berpengaruh signifikan positif terhadap hasil belajar.

Kata Kunci: Motivasi Belajar, Gaya Belajar, Lingkungan Belajar, Hasil Belajar
\end{abstract}

\section{ABSTRACT}

This study aims to analyze the influence of learning motivation, learning styles and learning environments on learning outcomes economy partially or simultaneously. The population in this study is IPS students a total of 314 people and a total sample of 153 students in SMA Negeri 1 Wringinanom Gresik. The data collection techniques used were questionnaires and documentation. Analysis method using multiple linear regression techniques. The results showed that the learning motivation, learning style and learning environment partially positive significant effect on learning outcomes. Learning motivation, learning style and the learning environment simultaneously positive significant effect on learning outcomes.

Keywords: Learning Motivation, Learning Styles, Learning Environment, Learning Outcomes

\section{PENDAHULUAN}

Perkembangan dan masa depan bangsa salah satunya ditentukan oleh kualitas sumber daya manusianya. Pendukung sumber daya manusia diantaranya adalah kualitas pendidikan yang baik. Sehingga peran pendidikan sangat penting untuk menciptakan masyarakat yang berguna bagi bangsa Indonesia. Dalam meningkatkan kualitas pendidikan salah satu yang terpenting adalah dengan meningkatkan kemampuan guru untuk berinteraksi dengan siswa pada proses belajar mengajar berlangsung. Guru harus mempunyai pengetahuan yang luas dan pemahaman yang lebih dalam mendidik siswa agar tercapainya tujuan pembelajaran. 
Tercapainya tujuan pembelajaran dalam proses belajar mengajar dapat dilihat dari hasil belajar siswa. Dimyati dan Mudjiono (2009) mengatakan bahwa hasil belajar merupakan hal yang dapat dipandang dari dua sisi yaitu dari sisi siswa dan dari sisi guru. Dari sisi siswa, hasil belajar merupakan tingkat perkembangan mental yang lebih baik bila dibandingkan pada saat sebelum belajar. Tingkat perkembangan mental terwujud pada jenis-jenis ranah kognitif, afektif dan psikomotorik. Sedangkan dari sisi guru hasil belajar merupakan saat terselesaikannya bahan pelajaran.

Berdasarkan observasi yang dilakukan oleh peneliti di SMA Negeri 1 Wringinanom gresik diperoleh informasi bahwa terdapat 10 kelas IPS antara lain X IPS terdapat 4 kelas dengan jumlah 125 siswa, XI IPS terdapat 3 kelas dengan jumlah 93 siswa, dan XII IPS terdapat 3 kelas dengan jumlah 96 siswa. Informasi selanjutnya diperoleh bahwa Kriteria Ketuntasan Minimal (KKM) untuk mata pelajaran ekonomi adalah 75 , sedangkan ketuntasan klasikal adalah $\geq 75 \%$. fenomena yang terjadi saat ini menunjukkan bahwa hasil belajar siswa pada mata pelajaran ekonomi kelas X, XI, XII IPS dengan jumlah siswa 314 siswa masih tergolong rendah, hal ini dapat dilihat dari daftar nilai UAS semester 1 terdapat $31 \%$ atau 97 siswa dari total semua siswa nilainya belum dapat mencapai 75 sehingga harus mengikuti remidial. Sedangkan 69\% atau 217 siswa lainnya telah memenuhi standar kriteria ketuntasan minimal (KKM). Selama ini siswa kurang aktif dalam proses belajar mengajar dan masih sulit dalam memahami materi yang disampaikan sehingga siswa kesulitan untuk mencapai hasil belajar yang maksimal.

Pencapaian siswa dalam hasil belajarnya tidak lepas dari berbagai faktor yang mempengaruhi belajar itu sendiri. Menurut Syah (2005) faktor yang mempengaruhi hasil belajar siswa dapat dibedakan menjadi tiga macam yaitu faktor internal, faktor eksternal dan faktor pendekatan belajar. Faktor internal merupakan salah satu faktor yang berasal dari dalam siswa untuk menentukan keberhasilan pembelajaran karena dalam proses belajar mengajar sasaran utama adalah siswa itu sendiri sebagai subyek belajar.

Faktor internal siswa yang dapat menunjang keberhasilan siswa salah satunya adalah motivasi belajar. Menurut Djamarah (2011) dalam proses belajar, motivasi belajar sangat diperlukan karena seseorang yang tidak mempunyai motivasi dalam belajar tidak akan mungkin melakukan aktivitas belajar. Fenomena yang terjadi saat ini adalah motivasi dalam diri siswa untuk belajar masih rendah, hal ini dapat dilihat dari siswa yang kurang aktif bertanya, menjawab, dan menyampaikan pendapat sehingga dalam proses belajar pada pelajaran ekonomi dikelas masih kurang. Siswa yang memiliki motivasi tinggi akan mempunyai banyak energi untuk melakukan aktivitas belajar karena motivasi yang tinggi akan membuat siswa tertarik dan terlibat aktif dalam proses pembelajaran.

Motivasi belajar sangat dibutuhkan oleh siswa dalam proses pembelajaran untuk mencapai keberhasilan siswa. Menurut Uno (2008) indikator motivasi belajar dari dalam diri siswa yaitu adanya hasrat keinginan berhasil, adanya dorongan dan kebutuhan dalam belajar, adanya harapan dan cita-cita masa depan. Menurut Nurtilawati (2012) dalam penelitiannya didapatkan hasil bahwa motivasi belajar berpengaruh sebesar $88 \%$ terhadap hasil belajar ekonomi. 
Dengan adanya motivasi belajar dari dalam diri siswa maka akan lebih mudah untuk mendapatkan hasil belajar yang maksimal.

Hasil belajar yang maksimal selain didapatkan dari motivasi belajar salah satunya adalah dari gaya belajar siswa. Menurut Susilo (2006) gaya belajar adalah cara yang cenderung dipilih seseorang untuk menerima informasi dari lingkungan dan memproses informasi tersebut. Setiap siswa memiliki gaya belajar masingmasing dalam proses belajar. Menurut Deporter dan Hernacki (2001) model gaya belajar itu mencakup gaya belajar visual, gaya belajar auditorial dan gaya belajar kinestetik yang artinya tidak semua siswa memiliki gaya belajar yang sama. Fenomena yang terjadi saat ini adalah proses pembelajaran yang berlangsung pada mata pelajaran ekonomi masih menggunakan model pembelajaran konvensional. Pembelajaran konvensional yang dimaksud adalah pembelajaran dengan menggunakan model yang biasa dilakukan oleh guru yaitu memberi materi melalui ceramah. Guru memiliki anggapan bahwa penerimaan pembelajaran ekonomi setiap siswa memiliki tingkatan yang seragam, sehingga disampaikan dengan metode ceramah. Nurtilawati (2012) dalam penelitiannya didapatkan hasil bahwa gaya belajar berpengaruh sebesar $24 \%$ terhadap hasil belajar ekonomi. Dengan memahami gaya belajar siswa, guru akan lebih mudah dalam menyampaikan materi kepada siswa agar hasil belajar siswa menjadi maksimal.

Hasil belajar yang maksimal selain didukung dari faktor internal siswa juga perlu didukung dari faktor eksternal siswa. Adapun faktor eksternal yang mempengaruhi hasil belajar siswa yaitu lingkungan belajar. Menurut Suwarno (2006) lingkungan belajar adalah lingkungan yang melingkupi terjadinya proses pendidikan dimana lingkungan belajar merupakan salah satu faktor yang mempengaruhi keberlangsungan kegiatan belajar yang baik.

Slameto (2010) berpendapat bahwa siswa yang belajar akan menerima pengaruh dari lingkungan sekolahnya. Faktor-faktor yang mempengaruhi meliputi: metode mengajar, kurikulum, relasi guru dengan siswa, relasi siswa dengan siswa, disiplin sekolah, alat pelajaran, waktu sekolah, standart pelajaran, keadaan gedung, metode belajar ,dan tugas rumah. Fenomena yang terjadi di lingkungan belajar ini masih terdapat siswa yang tidak menaati tata tertib sekolah seperti datang terlambat masuk kelas pada saat pembelajaran ekonomi berlangsung, masih terdapatnya siswa yang tidak mengerjakan tugas rumah pada mata pelajaran ekonomi, dan lingkungan belajar siswa di SMA Negeri 1 Wringinanom dirasakan oleh beberapa siswa masih kurang mendukung terhadap pencapaian hasil belajarnya karena ada beberapa kendala seperti pada saat pembelajaran ekonomi berlangsung terdapat 2 kelas yang masih direnovasi sehingga siswa baik kelas X, XI dan XII secara bergantian menggunakan kelas labolatorium untuk belajar ekonomi. Partono (2004) dalam penelitiannya didapatkan hasil bahwa lingkungan belajar berpengaruh sebesar $18,57 \%$ terhadap prestasi belajar ekonomi.

Berdasarkan penelitian yang dilakukan oleh Sari (2012) dimana hasil penelitian menunjukkan bahwa tidak ada pengaruh gaya belajar siswa yang signifikan terhadap hasil belajar, sedangkan penelitian yang dilakukan oleh Nurtilawati (2012) menunjukkan hasil bahwa terdapat pengaruh gaya belajar siswa yang signifikan terhadap hasil belajar. Dengan adanya perbedaan hasil penelitian tersebut peneliti tertarik untuk mengadakan penelitian di SMA Negeri 1 Wringinanom Gresik dengan judul "Pengaruh Motivasi Belajar, Gaya Belajar, dan 
Lingkungan Belajar pada Hasil Belajar Ekonomi di SMA Negeri 1 Wringinanom Gresik"

Motivasi menurut Dimyati (2009) adalah sebagai dorongan mental yang menggerakkan dan mengarahkan perilaku manusia, termasuk perilaku dalam belajar. Uno (2008) berpendapat bahwa motivasi adalah kekuatan dari dalam maupun dari luar yang mendorong seseorang untuk mencapai tujuan tertentu yang telah ditetapkan sebelumnya. Dari beberapa pengertian ini dapat di pahami bahwa motivasi belajar merupakan sesuatu yang mendorong siswa untuk belajar dan memahami materi yang dipelajari.

Dalam penelitian ini hanya menggunakan motivasi belajar intrinsik. Indikator motivasi belajar intrinsik menurut Uno (2008) adalah sebagai berikut: (a) Adanya hasrat keinginan berhasil; (b) Adanya dorongan dan kebutuhan dalam belajar; (c) Adanya harapan dan cita-cita masa depan. Motivasi belajar intrinsik dapat dipahami bahwa adanya hasrat keinginan berhasil, dorongan dan kebutuhan dalam belajar, dan harapan dan cita-cita masa depan merupakan motivasi yang timbul dari dalam diri seseorang berdasarkan kesadaran untuk melakukan suatu tindakan untuk mencapai tujuan belajar.

Siswa memiliki cara tersendiri dalam belajar sesuai dengan keinginan dan kemampuan mereka, yang biasa disebut gaya belajar. Secara sederhana dapat dikatakan bahwa gaya belajar adalah cara-cara yang digunakan untuk mempermudah proses belajar. Menurut Nasution (2003) Gaya belajar adalah cara yang dilakukan siswa dalam menangkap suatu informasi dengan cara mengingat, berpikir dan memecahkan masalah, dimana berkaitan dengan pribadi seseorang yang dipengaruhi oleh pendidikan dan riwayat perkembangannya.

Susilo (2006) berpendapat bahwa gaya belajar adalah cara yang cenderung dipilih seseorang untuk menerima informasi dari lingkungan dan memproses informasi tersebut. Berdasarkan pengertian diatas dapat disimpulkan bahwa gaya belajar adalah cara seseorang dalam menyerap informasi, mengingat informasi tersebut dan cara berpikir dalam memecahkan masalah yang didasarkan kepribadian siswa tersebut.

Beberapa ahli mengemukakan tentang jenis gaya belajar diantaranya adalah DePorter dan Hernacki (2001) berpendapat tentang model gaya belajar itu mencakup gaya belajar visual, gaya belajar auditorial dan gaya belajar kinestetik. Setelah memahami gaya belajar, maka tiap orang diharapkan dapat menentukan langkah-langkah supaya belajar lebih cepat dan mudah sesuai dengan kondisi tiap individu.

Gaya belajar visual cenderung lebih dominan dalam pengelihatannya dibanding dengan pendengaran ataupun gerakan-gerakan. Gaya belajar visual akan cenderung lebih khusus belajar melihat pada focus telaahnya. Beberapa menurut Deporter dan Hernacki (2001) yang digunakan dalam penelitian ini ciriciri gaya belajar visual sebagai berikut: (a) Rapi dan teratur; (b) Teliti dan mendetail; (c) Mengingat dengan asosiasi visual; (d) Mengalami kesulitan mengingat instruksi verbal.

Ciri-ciri gaya belajar visual tersebut yang memegang peranan penting yaitu mata/penglihatan sehingga dalam hal ini penggunaan metode pengajaran guru lebih dititikberatkan pada peragaan atau media, ajak mereka ke objek-objek berkaitan dengan pelajaran tersebut, atau dengan cara menunjukkan alat peraga langsung pada siswa atau menggambarkannya dipapan tulis. Gaya belajar visual 
harus melihat bahasa tubuh dan ekspresi muka dari gurunya supaya mengerti materi pelajarannya. Mereka cenderung memilih duduk di depan agar dapat melihat dengan jelas. Mereka berpikir menggunakan gambar di otak mereka dan belajar lebih cepat dengan menggunakan tampilan visual, seperti gambar diagram, buku pelajaran bergambar, video dan lebih suka mencatat sampai detil-detilnya dalam mendapatkan informasi.

Gaya belajar auditorial cenderung melalui suara dalam proses pembelajaran berlangsung. Beberapa menurut Deporter dan Hernacki (2001) yang digunakan dalam penelitian ini ciri-ciri gaya belajar auditorial diantaranya: (a) Belajar dengan mendengarkan dan mengingat apa yang didengarkan; (b) Kesulitan dalam pekerjaan yang melibatkan visualisasi; (c) Lebih pandai mengeja dengan suara keras daripada menuliskannya; (d) Lebih suka gurauan lisan daripada cerita lucu dari komik.

Ciri-ciri gaya belajar auditorial tersebut dapat disimpulkan bahwa siswa yang mempunyai gaya belajar ini dapat belajar lebih cepat dengan menggunakan diskusi verbal dan mendengarkan penjelasan guru. Gaya belajar auditorial dapat mencerna makna penyampaian melalui suara, kecepatan berbicara dan hal-hal lain yang bersifat mendengarkan. Siswa seperti ini biasanya dapat menghafal lebih cepat dengan membaca dengan bersuara keras serta melalui media seperti kaset dan lain-lain.

Gaya belajar kinestetik memiliki gaya belajar dengan melakukan segala sesuatu dengan secara langsung melalui gerak dan sentuhan fisik. Beberapa menurut Deporter dan Hernacki (2001) yang digunakan dalam penelitian ini ciriciri gaya belajar kinestetik diantaranya: (a) Menanggapi perhatian fisik; (b) Menyentuh orang untuk menarik perhatian mereka; (c) Banyak menggunakan isyarat tubuh; (d) Selalu ingin mempraktekkan segala sesuatu.

Proses belajar mengajar di lingkungan merupakan salah satu faktor yang mempengaruhi terhadap proses pembelajaran berlangsung didalamnya. Menurut Hamalik (2011) Lingkungan adalah sesuatu yang ada di alam sekitar yang memiliki makna atau pengaruh tertentu kepada individu. Dalam pendidikan, lingkungan merupakan semua faktor terkait dengan proses belajar dalam pendidikan. Suwarno (2006) berpendapat bahwa lingkungan belajar adalah lingkungan yang melingkupi terjadinya proses pendidikan. Dari pengertian diatas dapat di pahami bahwa lingkungan belajar merupakan salah satu faktor yang mempengaruhi keberlangsungan kegiatan belajar.

Tirtarahardja (2005) berpendapat bahwa sepanjang hidupnya manusia selalu dipengaruhi oleh tiga lingkungan pendidikan yaitu lingkungan keluarga, lingkungan sekolah, dan lingkungan masyarakat. Pada penelitian ini peneliti memberi batasan hanya pada lingkungan sekolah.Lingkungan sekolah merupakan lembaga pendidikan formal dimana kegiatan belajar mengajar berlangsung. Menurut Hamalik (2011) sekolah merupakan suatu lembaga yang memberikan pengajaran kepada murid-muridnya. Sekolah dapat mengembangkan dan meningkatkan pola pikir anak karena di sekolah mereka dapat belajar bermacammacam ilmu pengetahuan.

Dalyono (2009) menyatakan bahwa keadaan sekolah mempengaruhi tingkat keberhasilan belajar. Kualitas guru, metode mengajarnya, kesesuaian kurikulum dengan kemampuan anak, keadaan fasilitas/perlengkapan sekolah, keadaan ruangan, jumlah murid perkelas, pelaksanaan tata tertib dan seterusnya yang 
semua itu turut mempengaruhi keberhasilan belajar. Syah (2005) menyebutkan bahwa lingkungan sekolah terdiri dari dua macam yaitu lingkungan sosial dan lingkungan non sosial. Lingkungan sosial sekolah yaitu meliputi para guru, para tenaga pendidik, dan teman sekelas, sedangkan lingkungan non sosial sekolah meliputi gedung sekolah, alat-alat belajar, cuaca dan sebagainya.

Slameto (2010) berpendapat bahwa siswa yang belajar akan menerima pengaruh dari lingkungan sekolahnya. Faktor-faktor dari lingkungan sekolah yang dapat mempengaruhi belajar siswa meliputi: metode mengajar, kurikulum, relasi guru dengan siswa, relasi siswa dengan siswa, disiplin sekolah,alat pelajaran, waktu sekolah, standar pelajaran, keadaan gedung, metode belajar, tugas rumah.

Siswa dalam belajar tidak hanya belajar di salah satu lingkungan saja tetapi siswa belajar di semua lingkungan karena lingkungan-lingkungan tersebut merupakan lingkungan belajar bagi siswa dimana lingkungan itu akan saling mendukung satu sama lain untuk mencapai hasil belajar siswa yang baik. Indikator lingkungan sekolah yang digunakan dalam penelitian ini adalah keadaan sekolah tempat belajar, metode mengajar guru, keadaan gedung sekolah dan fasilitas sekolah, hubungan antara siswa dan guru, dan pelaksanaan tata tertib sekolah.

Menurut Djamarah (2011) hasil belajar dapat diartikan sebagai hasil akhir pengambilan keputusan tentang tinggi rendahnya nilai siswa selama mengikuti proses belajar mengajar, pembelajaran dikatakan berhasil jika tingkat pengetahuan siswa bertambah dari hasil sebelumnya. Dimyati dan Mudjiono (2009) menyatakan bahwa hasil belajar merupakan hal yang dapat dipandang dari dua sisi yaitu sisi siswa dan sisi guru. Dari sisi siswa, hasil belajar merupakan tingkat perkembangan mental yang lebih baik bila dibandingkan pada saat sebelum belajar. Tingkat perkembangan mental tersebut terwujud pada jenis-jenis ranah kognitif, afektif dan psikomotorik. Dari sisi guru hasil belajar merupakan saat terselesaikannya bahan pelajaran .

Hamalik (2011) hasil belajar adalah apabila seseorang telah belajar akan terjadi perubahan tingkah laku pada orang tersebut, misalnya dari yang tidak tahu menjadi tahu, dari yang tidak mengerti menjadi mengerti. Menurut Sudjana (2012) hasil belajar adalah kemampuan-kemampuan yang dimiliki siswa setelah ia menerima pengalaman belajar. Sedangkan menurut Tu'u (2004) hasil belajar adalah ditunjukkan dengan nilai tes angka atau nilai yang diberikan guru tertuang dalam bentuk skor yang diperolah siswa di sekolah. Skor yang diperoleh tersebut biasanya dimasukkan ke dalam bentuk laporan yang disebut nilai ulangan harian maupun ujian akhir semester.

Berdasarkan pendapat beberapa ahli tersebut, maka dapat dipahami bahwa hasil belajar merupakan suatu penilaian akhir dari proses dan pengenalan yang telah dilakukan berulang-ulang, serta akan tersimpan dalam jangka waktu lama atau bahkan tidak akan hilang selama-lamanya karena hasil belajar akan turut serta membentuk pribadi individu yang selalu ingin mencapai hasil yang lebih baik sehingga akan membawa perubahan perilaku yang terjadi setelah mengikuti proses belajar mengajar sesuai dengan tujuan pendidikan. Umumnya proses belajar siswa dalam sekolah berbentuk pemberian nilai dari guru kepada siswa sebagai indikasi sejauh mana siswa telah menguasai materi pelajaran yang disampaikan oleh guru. Oleh karena itu dalam penelitian ini hasil belajar yang dimaksudkan adalah nilai UAS. 
Dengan demikian tujuan penelitian ini antara lain: (a) Menganalisis pengaruh motivasi belajar, gaya belajar, dan lingkungan belajar pada hasil belajar ekonomi secara parsial; (b) Menganalisis pengaruh motivasi belajar, gaya belajar, dan lingkungan belajar pada hasil belajar ekonomi secara smultan.

\section{METODE PENELITIAN}

Pendekatan yang digunakan dalam penelitian ini adalah pendekatan kuantitatif sedangkan variabel dalam penelitian ini adalah motivasi belajar $\left(\mathrm{X}_{1}\right)$, gaya belajar $\left(\mathrm{X}_{2}\right)$ dan lingkungan belajar $\left(\mathrm{X}_{3}\right)$ sebagai variabel independen, dan hasil belajar (Y) sebagai variabel dependen. Populasi dalam penelitian ini adalah seluruh siswa kelas X, XI, XII Jurusan IPS di SMA Negeri 1 Wringinanom Gresik yang berjumlah 314 siswa. Sedangkan sampel penelitian ditentukan dengan menggunakan rumus slovin dengan Besarnya $e$ : $10 \%$.dan diperoleh ukuran sampel sebesar 124. Teknik sampling yang digunakan dalam penelitian ini menggunakan teknik propotional random sampling.

Metode pengumpulan data yang digunakan dalam penelitian ini adalah Angket dan dokumentasi. Kuesioner yang digunakan mengungkap variabel motivasi belajar, gaya belajar dan lingkungan belajar. Metode analisis data yang digunakan dalam penelitian ini adalah analisis deskriptif dan regresi berganda. Analisis deskriptif digunakan untuk mengetahui motivasi belajar, gaya belajar, lingkungan belajar dan hasil belajar siswa. Sedangkan analisis regresi digunakan untuk mengetahui besarnya hubungan antara variabel bebas dengan variabel terikat baik secara parsial maupun secara simultan.

\section{HASIL PENELITIAN DAN PEMBAHASAN}

\section{Hasil Penelitian}

Analisis dalam penelitian ini menggunakan analisis regresi berganda yang berfungsi untuk mengetahui ada tidaknya pengaruh antara ketiga variabel yaitu variabel motivasi belajar intrinsik (X1), gaya belajar (X2), dan Lingkungan belajar sekolah (X3) terhadap hasil belajar siswa (Y). Variabel bebas terhadap variabel terikat dilakukan analisis regresi linier berganda dengan persamaan regresi sebagai berikut: $\mathrm{Y}=16.459+0.827 \mathrm{X}_{1}+0.085 \mathrm{X}_{2}+0.327 \mathrm{X}_{3}+$ e. Dari persamaan regresi linier berganda dapat dijelaskan:

1. Konstanta $(\alpha)$ sebesar 16.459 artinya bahwa dengan menganggap semua variabel bebas sama dengan 0, maka hasil belajar UAS siswa pada mata pelajaran ekonomi program studi IPS di SMA Negeri 1 Wringinanom Gresik dalam kondisi positif dengan nilai 16.459.

2. Koefisien Motivasi belajar intrinsik $\left(b_{1}\right)$ sebesar 0,827 artinya bahwa setiap peningkatan satu persen motivasi belajar siswa pada mata pelajaran ekonomi program studi IPS di SMA Negeri 1 Wringinanom Gresik, maka hasil belajar UAS siswa pada mata pelajaran ekonomi program studi IPS di SMA Negeri 1 Wringinanom Gresik akan mengalami peningkatan sebesar 0,827 persen. Dalam hal ini faktor lain yang mempengaruhi hasil belajar UAS siswa pada mata pelajaran ekonomi program studi IPS di SMA Negeri 1 Wringinanom Gresik dianggap tetap. 
3. Koefisien regresi gaya belajar $\left(b_{2}\right)$ sebesar 0,085 artinya bahwa setiap peningkatan satu persen gaya belajar pada siswa pada mata pelajaran ekonomi program studi IPS di SMA Negeri 1 Wringinanom Gresik, maka hasil belajar UAS siswa pada mata pelajaran ekonomi program studi IPS di SMA Negeri 1 Wringinanom Gresik akan mengalami peningkatan sebesar 0,085 persen. Dalam hal ini faktor lain yang mempengaruhi hasil belajar UAS siswa pada mata pelajaran ekonomi program studi IPS di SMA Negeri 1 Wringinanom Gresik dianggap tetap.

4. Koefisien regresi lingkungan belajar sekolah $\left(b_{3}\right)$ sebesar 0,327 artinya bahwa setiap peningkatan satu persen gaya belajar pada siswa pada mata pelajaran ekonomi program studi IPS di SMA Negeri 1 Wringinanom Gresik, maka hasil belajar UAS siswa pada mata pelajaran ekonomi program studi IPS di SMA Negeri 1 Wringinanom Gresik akan mengalami peningkatan sebesar 0,327 persen. Dalam hal ini faktor lain yang mempengaruhi hasil belajar UAS siswa pada mata pelajaran ekonomi program studi IPS di SMA Negeri 1 Wringinanom Gresik dianggap tetap.

Berdasarkan data yang telah diolah dapat diketahui bahwa hasil uji-F probabilitas value ( $\mathrm{sig}$ ) dalam penelitian ini adalah $0,000<0,05$ dengan demikian $\mathrm{H}_{0}$ ditolak dan Ha diterima, sehingga dapat disimpulkan bahwa secara simultan (bersama-sama) variabel bebas motivasi belajar intrinsik, gaya belajar dan lingkungan belajar sekolah berpengaruh signifikan dan positif terhadap hasil belajar UAS siswa pada mata pelajaran ekonomi program studi IPS di SMA Negeri 1 Wringinanom Gresik.

Besarnya pengaruh motivasi belajar intrinsik, gaya belajar dan lingkungan belajar sekolah secara simultan terhadap hasil belajar UAS dapat diketahui dari nilai Ajusted R-square yang dihasilkan sebesar 0,766 yang menunjukkan bahwa hasil belajar UAS dipengaruhi oleh motivasi belajar intrinsik, gaya belajar dan lingkungan belajar sekolah sebesar 76\% sedangkan 24\% dipengaruhi oleh faktorfaktor lain selain variabel motivasi belajar intrinsik, gaya belajar dan lingkungan belajar sekolah.

Selanjutnya pengujian variabel motivasi belajar, gaya belajar dan lingkungan belajar secara parsial maka dilakukan dengan menggunakan uji parsial (Uji t) dan didapatkan hasil sebagai berikut:

1. Variabel $X_{1}$ motivasi belajar intrinsik memiliki signifikansi (sig) $=0,000<$ taraf signifikansi $\alpha=0,05$, maka dapat disimpulkan bahwa ada pengaruh yang positif dan signifikan motivasi belajar intrinsik terhadap hasil belajar UAS siswa pada mata pelajaran ekonomi program studi IPS di SMA Negeri 1 Wringinanom Gresik.

2. Variabel $X_{2}$ gaya belajar memiliki signifikansi (sig) $=0,037<$ taraf signifikansi $\alpha=0,05$ maka dapat disimpulkan bahwa ada pengaruh yang positif dan signifikan gaya belajar terhadap hasil belajar UAS siswa pada mata pelajaran ekonomi program studi IPS di SMA Negeri 1 Wringinanom Gresik.

3. Variabel $X_{3}$ lingkungan belajar sekolah memiliki signifikansi (sig) $=0,000<$ taraf signifikansi $\alpha=0,05$ maka dapat disimpulkan bahwa ada pengaruh yang positif dan signifikan gaya belajar terhadap hasil belajar UAS siswa pada mata pelajaran ekonomi program studi IPS di SMA Negeri 1 Wringinanom Gresik.

Setelah dilakukan uji-t dapat diperoleh bahwa nilai $r^{2}$ parsial sebagai berikut: 
1. Nilai $r^{2}$ parsial pada variabel motivasi belajar $\left(\mathrm{X}_{1}\right)$ sebesar 0,414 menunjukkan bahwa motivasi belajar $\left(\mathrm{X}_{1}\right)$ secara parsial berpengaruh terhadap prestasi belajar (Y) sebesar $41 \%$.

2. Nilai $r^{2}$ parsial pada variabel gaya belajar $\left(\mathrm{X}_{2}\right)$ sebesar 0,028 menunjukkan bahwa gaya belajar $\left(\mathrm{X}_{2}\right)$ secara parsial berpengaruh terhadap prestasi belajar (Y) sebesar $2 \%$.

3. Nilai $r^{2}$ parsial pada variabel lingkungan belajar $\left(\mathrm{X}_{3}\right)$ sebesar 0,102 menunjukkan bahwa lingkungan belajar $\left(\mathrm{X}_{3}\right)$ secara parsial berpengaruh terhadap prestasi belajar (Y) sebesar $10 \%$.

\section{Pembahasan}

1. Pengaruh Motivasi Belajar Terhadap Hasil Belajar Siswa

Berdasarkan hasil analisis regresi linier berganda mengenai pengaruh motivasi belajar pada hasil belajar siswa di SMA Negeri 1 Wringinanom menunjukkan bahwa motivasi belajar berpengaruh signifikan dan positif terhadap hasil belajar, yang berarti tingginya motivasi belajar berdampak nyata pada tingginya hasil belajar. Jika motivasi belajar naik maka hasil belajar juga akan naik dengan asumsi variabel bebas lainnya dianggap tetap. Nilai positif pada variabel ini menunjukkan bahwa motivasi belajar memiliki hubungan yang searah dengan hasil belajar siswa yaitu semakin tinggi motivasi belajar maka semakin tinggi hasil belajar siswa.

Temuan ini menunjukkan bahwa motivasi belajar berpengaruh pada hasil belajar siswa seperti hasil penelitian terdahulu yang dilakukan oleh Rejeki (2012) yang menyimpulkan bahwa motivasi belajar mempengaruhi hasil belajar. Hasil penelitian ini juga didukung oleh hasil penelitian terdahulu Wiyono (2003), Dwija (2008), Hamdu (2011), dan Rahman (2011) bahwa motivasi belajar berpengaruh signifikan dan positif terhadap hasil belajar siswa. Hasil penelitian ini sesuai dengan pernyataan Hamalik (2011) yang menyatakan bahwa motivasi belajar sebagai pengaruh yang artinya mengarahkan perbuatan kepada pencapaian tujuan yang diinginkan yaitu hasil belajar. Menurut Djamarah (2011) mengemukakan bahwa dalam proses belajar, motivasi belajar sangat diperlukan sebab seseorang yang tidak mempunyai motivasi dalam belajar tidak akan mungkin melakukan aktivitas belajar. Sehingga dengan aktivitas belajar maka akan mempengaruhi hasil belajar. Penelitian terdahulu yang dilakukan di luar negeri juga mendukung hasil penelitian ini yaitu penelitian yang dilakukan oleh Lee (2010) dan Sarwah (2012) yang hasilnya terdapat pengaruh yang signifikan antara motivasi belajar terhadap prestasi belajar.

Menurut Sardiman (2009) Motivasi intrinsik adalah motivasi yang aktif atau berfungsinya tidak perlu dirangsang dari luar, karena di dalam diri setiap individu ada dorongan untuk melakukan sesuatu. Sesuai dengan penelitian ini bahwa motivasi belajar berpengaruh terhadap hasil belajar siswa. Dengan adanya motivasi dalam diri siswa maka siswa melakukan aktifitas belajar. Motivasi belajar intrinsik siswa pada penelitian ini terdapat tiga indikator yaitu hasrat dan keinginan berhasil, dorongan dan kebutuhan belajar dan harapan dan cita-cita masa depan. Berdasarkan jawaban pada indikator motivasi belajar hasrat dan keinginan berhasil menunjukkan rerata dengan kategori sangat tinggi yang artinya siswa memiliki keinginan berhasil yang tinggi untuk 
mendapatkan nilai yang baik disekolah, selanjutnya adalah indikator dorongan dan kebutuhan belajar yang menunjukkan rerata dengan kategori sangat tinggi yang artinya siswa memiliki kebutuhan dalam belajar sehingga siswa belajar lebih giat untuk memperoleh pemahaman pada pelajaran ekonomi. Dan yang terakhir adalah indikator harapan dan cita-cita masa depan menunjukkan rerata dengan kategori tinggi yang berarti siswa memiliki cita-cita masa depan yang tinggi sehingga untuk mencapai cita-cita yang diinginkannya siswa lebih giat untuk belajar.

Berdasarkan temuan hasil penelitian variabel motivasi belajar pada masing-masing indikator maka dapat diurutkan jawaban tertinggi sampai terendah yaitu urutan pertama terdapat dua indikator yang memiliki rerata yang sama tinggi yaitu indikator hasrat keinginan berhasil dan dorongan dan kebutuhan dalam belajar. Untuk urutan terendah adalah indikator harapan dan cita-cita masa depan. Sehingga dapat dipahami bahwa pada indikator harapan dan cita-cita masa depan dapat lebih ditingkatkan dengan cara guru memberikan motivasi agar siswa dapat mencapai cita-citanya.

Berdasarkan uraian tersebut dapat disimpulkan bahwa siswa SMA Negeri 1 Wringinanom Gresik secara umum memiliki motivasi belajar yang bagus. Dengan demikian maka guru mata pelajaran ekonomi dalam memberikan materi pelajaran dapat memberikan tambahan motivasi kepada siswa agar motivasi belajar siswa tetap tinggi dan hasil belajar siswa tidak menurun.

\section{Pengaruh Gaya Belajar Terhadap Hasil Belajar Siswa}

Berdasarkan hasil analisis regresi linier berganda diperoleh hasil bahwa secara statistik mengenai pengaruh gaya belajar pada hasil belajar siswa di SMA Negeri 1 Wringinanom menunjukkan bahwa gaya belajar berpengaruh signifikan dan positif terhadap hasil belajar. Jika gaya belajar naik maka hasil belajar akan naik dengan asumsi variabel bebas lainnya dianggap tetap. Nilai positif pada variabel ini menunjukkan bahwa gaya belajar memiliki hubungan yang searah dengan hasil belajar siswa yaitu semakin tinggi gaya belajar siswa maka semakin tinggi hasil belajar siswa.

Berdasarkan temuan hasil penelitian ini menunjukkan bahwa gaya belajar berpengaruh signifikan dan positif terhadap hasil belajar siswa, seperti hasil penelitian terdahulu yang dilakukan oleh Tanta (2010), Indarto (2011) Nurtilawati (2012), dan Rejeki (2012) yang menyatakan bahwa gaya belajar siswa berpengaruh signifikan dan positif terhadap hasil belajar.

Hasil penelitian ini tidak mendukung hasil penelitian terdahulu yang dilakukan oleh Prastiti (2009) dan Sari (2012) yang hasilnya adalah tidak pengaruh gaya belajar yang signifikan terhadap hasil belajar. Penelitian terdahulu tentang gaya belajar yang dilakukan di luar negeri oleh Hsieh (2007) dan Lu (2007) juga memiliki hasil bahwa tidak ada pengaruh gaya belajar yang signifikan terhadap hasil belajar.

Gaya belajar siswa dalam penelitian ini ada tiga gaya belajar yaitu gaya belajar visual, gaya belajar auditorial dan gaya belajar kinestetik. Hal ini sesuai dengan pernyataan DePorter dan Hernacki (2001) yang berpendapat tentang model gaya belajar itu mencakup gaya belajar visual, gaya belajar auditorial dan gaya belajar kinestetik. 
Susilo (2006) berpendapat bahwa gaya belajar adalah cara yang cenderung dipilih seseorang untuk menerima informasi dari lingkungan dan memproses informasi tersebut. Sesuai dengan penelitian ini bahwa gaya belajar berpengaruh terhadap hasil belajar. Siswa dalam menerima pelajaran ekonomi akan lebih mudah menerima pelajaran ekonomi jika materi pelajaran itu disampaikan sesuai dengan modalitas gaya belajar siswa yang digunakan dalam belajar ekonomi. Setelah dilakukan penelitian dapat diketahui bahwa secara keseluruhan siswa IPS kelas X, XI, XII IPS lebih kecenderungan menggunakan modalitas gaya belajar visual. Namun dari tingkatan kelas dapat diperoleh modalitas gaya belajar yang berbeda pada semester ganjil. Pada kelas $\mathrm{X}$ lebih kecenderungan menggunakan modalitas gaya belajar visual yang artinya pada semester ganjil mata pelajaran ekonomi kelas $X$ yang mencakup materi tentang permasalahan ekonomi dalam kaitannya dengan kebutuhan manusia, kelangkaan dan sistem ekonomi, kegiatan ekonomi konsumen dan produsen, permintaan dan penawaran, harga keseimbangan dan pasar mudah dipahami siswa dengan mengingat sesuatu berdasarkan asosiasi visual.

Selanjutnya untuk kelas XI lebih kecenderungan menggunakan modalitas gaya belajar auditorial yang artinya pada semester ganjil mata pelajaran ekonomi kelas XI yang mencakup tentang ketenagakerjaan dan dampak terhadap pembangunan ekonomi, APBN dan APBD, pasar modal dan perekonomian terbuka lebih mudah dipahami siswa dengan cara mendengarkan. Sedangkan untuk kelas XII yaitu lebih kecenderungan menggunakan modalitas gaya belajar visual yang artinya pada semester ganjil mata pelajaran ekonomi kelas XII yang mencakup tentang badan usaha dalam perekonomian nasional lebih mudah dipahami siswa materi dengan mengingat sesuatu berdasarkan asosiasi visual.

Berdasarkan uraian tersebut dapat disimpulkan bahwa siswa SMA Negeri 1 Wringinanom Gresik pada siswa kelas X pada semester ganjil menggunakan modalitas gaya belajar visual, sedangkan siswa kelas XI menggunakan modalitas gaya belajar auditorial dan siswa kelas XII menggunakan modalitas gaya belajar visual. Dengan demikian maka guru mata pelajaran ekonomi dapat menyesuaikan gaya belajar siswa agar materi yang disampaikan lebih mudah dipahami oleh siswa dan hasil belajar siswa meningkat.

\section{Pengaruh Lingkungan Belajar Terhadap Hasil Belajar Siswa}

Berdasarkan hasil analisis regresi linier berganda diperoleh hasil bahwa secara statistik mengenai pengaruh lingkungan belajar pada hasil belajar siswa di SMA Negeri 1 Wringinanom menunjukkan bahwa lingkungan belajar berpengaruh signifikan dan positif terhadap hasil belajar, yang berarti lingkungan belajar berdampak nyata pada tingginya hasil belajar. Jika lingkungan belajar naik maka hasil belajar akan naik dengan asumsi variabel bebas lainnya dianggap tetap. Nilai positif pada variabel ini menunjukkan bahwa lingkungan belajar memiliki hubungan yang searah dengan hasil belajar siswa yaitu semakin bagus lingkungan belajar maka semakin tinggi hasil belajar siswa.

Berdasarkan temuan hasil penelitian ini menunjukkan bahwa lingkungan belajar berpengaruh signifikan dan positif pada hasil belajar siswa seperti hasil penelitian terdahulu yang dilakukan oleh Wiyono (2003), Partono (2004), dan 
Rahman (2011) yang menyatakan bahwa lingkungan belajar berpengaruh signifikan dan positif terhadap hasil belajar. Dengan demikian semakin bagus lingkungan belajar siswa di sekolah maka akan semakin meningkat hasil belajar siswa dan sebaliknya. Penelitian terdahulu yang mendukung juga dilakukan di luar negeri oleh Schaper (2008) yang hasilnya adalah terdapat pengaruh positif dan signifikan terhadap prestasi belajar.

Menurut Hamalik (2011) Lingkungan adalah sesuatu yang ada di alam sekitar yang memiliki makna atau pengaruh tertentu kepada individu. Dalam pendidikan, lingkungan merupakan semua faktor terkait dengan proses belajar dalam pendidikan. Hal ini sesuai dengan penelitian ini bahwa lingkungan belajar sekolah mempengaruhi hasil belajar siswa. lingkungan belajar sekolah dalam penelitian ini indikatornya yaitu keadaan sekolah tempat belajar, metode mengajar guru, keadaan gedung sekolah dan fasilitas sekolah, hubungan antar siswa dan guru dan tata tertib sekolah.

Berdasarkan hasil penelitian variabel lingkungan belajar pada masingmasing indikator maka dapat diurutkan jawaban tertinggi sampai terendah yaitu pertama adalah indikator tata tertib sekolah dengan rerata kriteria tinggi yang berarti bahwa siswa memiliki rasa ketaatan yang tinggi dalam mematuhi tata tertib sekolah, kedua adalah indikator hubungan antar siswa dan guru dengan rerata kategori tinggi yang berarti hubungan antara siswa dan guru terjalin dengan baik sehingga siswa tidak mengalami kesulitan dalam bertanya pelajaran kepada guru, ketiga adalah indikator metode mengajar guru dengan rerata kategori tinggi yang berarti bahwa meskipun menggunakan metode konvensional digunakan oleh guru namun pembelajarannya cukup menarik bagi siswa sehingga siswa merasa senang dalam proses belajar, keempat adalah indikator keadaan gedung sekolah dan fasilitas sekolah dengan rerata kategori tinggi yang berarti bahwa siswa merasa lebih terbantu dengan adanya keadaan gedung yang layak dan adanya fasilitas sekolah yang mendukung dalam proses pembelajaran, dan yang kelima adalah indikator keadaan sekolah tempat belajar dengan rerata kategori cukup yang berarti bahwa meskipun terdapat kelas yang sedang direnovasi namun siswa masih merasa cukup nyaman untuk belajar. Sehingga dapat dipahami bahwa indikator terendah adalah keadaan sekolah tempat belajar yang berarti diusahakan untuk renovasi kelas segera terselesaikan sehingga siswa dapat belajar dengan nyaman dan dapat mendukung untuk meningkatkan hasil belajar siswa.

Berdasarkan uraian tersebut dapat disimpulkan bahwa siswa SMA Negeri 1 Wringinanom Gresik secara umum memiliki lingkungan belajar yang bagus. Dengan demikian maka dapat dipahami lingkungan sekolah yang bagus akan memberikan pengaruh kepada seluruh siswa untuk mencapai hasil belajar yang baik.

4. Pengaruh Motivasi Belajar, Gaya Belajar dan Lingkungan Belajar Terhadap Hasil Belajar Siswa

Berdasarkan hasil analisis regresi linier berganda diperoleh hasil bahwa secara statistik mengenai pengaruh motivasi belajar, gaya belajar dan lingkungan belajar pada hasil belajar siswa di SMA Negeri 1 Wringinanom menunjukkan bahwa secara simultan (bersama-sama) variabel bebas motivasi belajar, gaya belajar dan lingkungan belajar berpengaruh signifikan dan positif 
terhadap hasil belajar UAS siswa pada mata pelajaran ekonomi program studi IPS di SMA Negeri 1 Wringinanom Gresik. Besarnya pengaruh motivasi belajar intrinsik, gaya belajar dan lingkungan belajar sekolah secara simultan terhadap hasil belajar UAS dapat dilihat dari koefisien determinasi (R-square). Nilai R-square yang dihasilkan menunjukkan bahwa hasil belajar UAS dipengaruhi oleh motivasi belajar intrinsik, gaya belajar dan lingkungan belajar sekolah.

Berdasarkan temuan hasil penelitian ini menunjukkan bahwa motivasi belajar, gaya belajar dan lingkungan belajar berpengaruh signifikan dan positif pada hasil belajar siswa seperti hasil penelitian terdahulu yang meneliti variabel motivasi belajar dan lingkungan belajar dilakukan oleh Wiyono (2003) dan Rahman (2011) yang menyatakan bahwa lingkungan belajar dan motivasi belajar berpengaruh signifikan dan positif terhadap hasil belajar. Penelitian terdahulu yang meneliti variabel motivasi belajar dan gaya belajar dilakukan oleh Indarto (2011), Nurtilawati (2012) dan Rejeki (2012) yang hasilnya adalah motivasi belajar dan gaya belajar berpengaruh signifikan dan positif terhadap hasil belajar.

Berdasarkan uraian tersebut dapat disimpulkan bahwa kelas X, XI, XII IPS di SMA Negeri 1 Wringinanom Gresik secara umum motivasi belajar, gaya belajar dan lingkungan belajar berpengaruh signifikan dan positif terhadap hasil belajar ekonomi. Dengan demikian maka dapat dipahami motivasi belajar, gaya belajar dan lingkungan belajar yang bagus akan memberikan pengaruh kepada seluruh siswa untuk mencapai hasil belajar yang baik.

\section{KESIMPULAN}

1. Terdapat pengaruh motivasi belajar pada hasil belajar ekonomi di SMA Negeri 1 Wringinanom Gresik. Hal ini berarti motivasi belajar secara parsial berpengaruh signifikan dan positif pada hasil belajar ekonomi. Hasil temuan pada penelitian ini lebih dominan didukung oleh dua indikator motivasi belajar yaitu hasrat keinginan berhasil dan dorongan kebutuhan dalam belajar. Hal ini dapat ditunjukkan dari temuan bahwa sebagian besar siswa berusaha keras untuk mendapatkan nilai yang baik disekolah dan memiliki dorongan kebutuhan dalam belajar untuk memperoleh pemahaman pelajaran ekonomi disekolah.

2. Terdapat pengaruh gaya belajar pada hasil belajar ekonomi di SMA Negeri 1 Wringinanom Gresik. Hal ini berarti gaya belajar secara parsial berpengaruh signifikan dan positif pada hasil belajar ekonomi. Hasil temuan pada penelitian ini lebih dominan didukung oleh indikator gaya belajar visual. Hal ini dapat ditunjukkan dari temuan bahwa sebagian besar siswa memiliki gaya belajar visual yang lebih dominan dalam belajar ekonomi. Siswa lebih mudah menggunakan modalitas gaya belajar pada pelajaran ekonomi dengan menggunakan asosiasi visual yaitu berupa gambar ataupun diagram

3. Terdapat pengaruh lingkungan belajar pada hasil belajar ekonomi di SMA Negeri 1 Wringinanom Gresik. Hal ini berarti lingkungan belajar secara parsial berpengaruh signifikan dan positif pada hasil belajar ekonomi. Hasil temuan pada penelitian ini lebih dominan didukung oleh indikator tata tertib sekolah. 
Hal ini dapat ditunjukkan dari temuan bahwa sebagian besar siswa memiliki ketaatan yang tinggi dalam mematuhi tata tertib sekolah.

4. Terdapat pengaruh motivasi belajar, gaya belajar dan lingkungan belajar pada hasil belajar ekonomi di SMA Negeri 1 Wringinanom Gresik. Hal ini berarti motivasi belajar, gaya belajar dan lingkungan belajar secara simultan berpengaruh signifikan dan positif pada hasil belajar ekonomi. Semakin tinggi motivasi belajar, gaya belajar dan lingkungan belajar maka semakin tinggi hasil belajar siswa SMA Negeri 1 Wringinanom Gresik. Hasil temuan pada penelitian ini menunjukkan bahwa diantara variabel-variabel tersebut yang lebih dominan berpengaruh pada hasil belajar adalah variabel motivasi belajar.

\section{DAFTAR RUJUKAN}

Dalyono. 2009. Psikologi Pendidikan. Jakarta: Rineka Cipta.

Deporter, Bobbi, dan Mike Hernacki. 2001. Quantum Learning Membiasakan Belajar Nyaman Dan Menyenangkan. Bandung: Kaifa.

Djamarah, Syaiful Bahri. 2011. Psikologi Belajar. Jakarta: PT Rineka Cipta.

Dimyati dan Mudjiono. 2009. Belajar dan Pembelajaran. Jakarta: Rineka Cipta.

Hamalik, Oemar. 2011. Perencanaan Pengajaran berdasarkan Pembekalan Baru. Jakarta: Sinar Grafika

Hsieh, Pei-Hsuan. 2007. The Effect Of Various Online Reading Strategies And Learning Styles On Student Achievement Of Different Learning Objectives. Tesis yang dipublikasikan.

Indarto, Danang. 2011. Pengaruh Gaya Belajar dan Motivasi Berprestasi Siswa Terhadap Prestasi Belajar Praktik Instalasi Listrik di Smk Negeri 2 Yogyakarta. Jurnal Penelitian Pendidikan.

Lee, I-Chao. 2010. The Effect Of Learning Motivation, Total Quality Teaching And Peer-Assisted Learning On Study Achievement: Empirical Analysis From Vocational Universities Or Colleges' Students In Taiwan. Journal of human Resource Vol 6.

Lu, Hong, Dkk. 2007. The Relationship of Kolb Learning Styles, Online Learning Behaviors and Learning Outcomes. Educational Technology and Society Vol 10 No 4.

Nasution, S. 2003. Berbagi Pendekatan Dalam Proses Belajar dan Mengajar. Jakarta: Bumi Aksara.

Nurtilawati, dkk. 2012. Pengaruh Gaya Belajar Dan Motivasi Belajar Terhadap Hasil Belajar Siswa Pada Mata Pelajaran Ekonomi Kelas X di SMAN 8 Pontianak. Jurnal Penelitian Pendidikan.

Partono dan Minarni, Tri. 2004. Pengaruh Disiplin dan Lingkungan Belajar Terhadap Prestasi Belajar Mata Pelajaran Ekonomi. Jurnal Penelitian Pendidikan.

Purwanto, Ngalim. 2006. Psikologi Pendidikan. Bandung: PT Remaja Ros.

Rahman, Avif Roy. 2011. Pengaruh Motivasi, Lingkungan dan Disiplin Terhadap Prestasi Belajar Siswa Pada Jurusan Teknik Audio Video Smk Negeri 3 Yogyakarta. Jurnal Penelitian Pendidikan.

Rejeki, Sri. 2012. Pengaruh Kondisi Ekonomi keluarga, Motivasi Belajar, dan Gaya Belajar Terhadap Hasil Belajar Siswa. Jurnal Penelitian Pendidikan. 
Sari, Nuniek Pradita. 2012. Pengaruh Gaya Belajar Terhadap Prestasi Belajar Matematika Siswa. Jurnal Penelitian Pendidikan.

Sarwar, Gul Shahzad, Dkk. 2012. Teaching Practice and Student Motivation that Influence Achievement on Large-Scale Assesment. International Journal of Education Vol 4 No 3.

Schaper, Elizabeth A. 2008. The Impact Of Middle School Students' Perceptions Of The Classroom Learning Environment On Achievement In Mathematics. Desertasi yang dipublikasikan.

Slameto. 2010. Belajar dan Faktor-faktor yang Mempengaruhi. Jakarta : Rineka Cipta.

Sudjana, Nana. 2012. Penilaian Hasil Proses Belajar Mengajar. Bandung : PT Remaja Rosdakarya.

Susilo, M, Joko. 2006. Gaya Belajar Menjadikan Lebih Pintar. Yogyakarta: Pinus.

Suwarno, Wiji. 2006. Dasar-dasar Ilmu Pendidikan. Jogjakarta : Ar Razz Media.

Syah, Muhibbin. 2005. Psikologi Pendidikan dengan Pendekatan Baru. Bandung: PT Remaja Rosdakarya.

Tanta. 2010. "Pengaruh Gaya Belajar Terhadap Hasil Belajar Mahasiswa Pada Mata kuliah Biologi Umum Program Studi Pendidikan Universitas Cendrawasih". Jurnal Kependidikan Dasar Volume 1 No. 1.

Tirtarahardja, Umar dan S.L La Sudo. 2005. Pengantar Penddikan. Jakarta: Rineka Cipta.

Tu'u, Tulus. 2004 .Peran Disiplin Pada Perilaku dan Prestasi Siswa. Jakarta: Grasindo.

Uno, Hamzah. 2008. Teori Motivasi dan Pengukurannya. Jakarta : Bumi Aksara 